\title{
Corrigendum: Marine Bioresource Development - Stakeholder's Challenges, Implementable Actions, and Business Models
}

\section{OPEN ACCESS}

Approved by:

Frontiers Editorial Office,

Frontiers Media SA, Switzerland

*Correspondence:

Jane Eva Collins

jane.collins@abs-int.eu

${ }^{\dagger}$ These authors share last authorship

Specialty section: This article was submitted to

Ocean Solutions,

a section of the journal Frontiers in Marine Science

Received: 27 February 2020

Accepted: 28 February 2020

Published: 13 March 2020

Citation:

Collins JE, Vanagt T, Huys I and Vieira H (2020) Corrigendum: Marine Bioresource Development -

Stakeholder's Challenges, Implementable Actions, and Business Models. Front. Mar. Sci. 7:158 doi: 10.3389/fmars.2020.00158

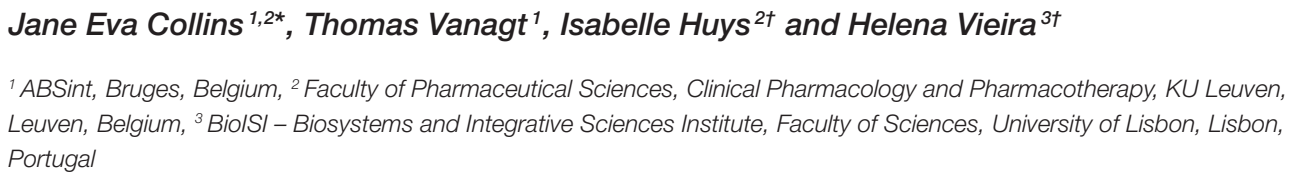
Leuven, Belgium, ${ }^{3} \mathrm{BiolSI}$ - Biosystems and Integrative Sciences Institute, Faculty of Sciences, University of Lisbon, Lisbon, Portugal

Keywords: marine biological resources, blue bioeconomy, blue biotechnology, business models, value chain, market, biodiversity, supply and technology

\section{A Corrigendum on}

Marine Bioresource Development - Stakeholder's Challenges, Implementable Actions, and Business Models

by Collins, J. E., Vanagt, T., Huys, I., and Vieira, H. (2020). Front. Mar. Sci. 7:62. doi: $10.3389 /$ fmars.2020.00062

In the original article, we neglected to include the funder FCT, Portugal (to BioISI), Research Unit grant number UIDB/04046/2020 to Helena Vieira.

The authors apologize for this error and state that this does not change the scientific conclusions of the article in any way. The original article has been updated.

Copyright (C) 2020 Collins, Vanagt, Huys and Vieira. This is an open-access article distributed under the terms of the Creative Commons Attribution License (CC BY). The use, distribution or reproduction in other forums is permitted, provided the original author(s) and the copyright owner(s) are credited and that the original publication in this journal is cited, in accordance with accepted academic practice. No use, distribution or reproduction is permitted which does not comply with these terms. 